\title{
Geosciencences
}

\section{Geochemical mapping of arsenic in surface waters and stream sediments of the Quadrilátero Ferrífero, Brazil}

http://dx.doi.org/10.1590/0370-44672015680077

\section{Raphael de Vicq Ferreira da Costa Doutorando \\ Universidade Federal de Ouro Preto. \\ Escola de Minas - Departamento de Geologia \\ Ouro Preto - Minas Gerais - Brazil \\ raphaelvicq@gmail.com}

\section{Mariangela Garcia Praça Leite \\ Professora Associada \\ Universidade Federal de Ouro Preto, \\ Escola de Minas - Departamento de Geologia \\ Ouro Preto - Minas Gerais - Brazil \\ mgpleite@gmail.com}

\section{Fellipe Pinheiro Chagas Mendonça \\ Doutorando \\ Universidade Federal de Ouro Preto, \\ Escola de Minas - Departamento de Geologia \\ Ouro Preto - Minas Gerais - Brazil \\ fellipe.chagas@gmail.com}

\section{Hermínio Arias Nalini Jr.}

Professor Associado IV

Universidade Federal de Ouro Preto,

Escola de Minas - Departamento de Geologia

Ouro Preto - Minas Gerais - Brazil

herminio.nalini@gmail.com

\section{Mapeamento geoquímico do arsênio em águas superficiais e sedimentos fluviais no Quadrilátero Ferrífero, Brasil}

Abstract

A regional study on the arsenic concentration in surface waters and stream sediments, with a density of one sample every $13 \mathrm{~km}^{2}$, was carried out for the first time in the Quadrilátero Ferrífero (Brazil). The region was divided into $3^{\text {rd }}$ order catchment basins, in which 512 areas were sampled. The arsenic concentration was determined in waters and stream sediments after partial digestion with the aid of ICP-OES. The arsenic values found in surface waters ranged from 57.70 to $414 \mu \mathrm{g} . \mathrm{L}^{-1}$, while for stream sediments, arsenic concentrations ranged from 0.63 to $1691 \mathrm{mg} \cdot \mathrm{kg}^{-1}$, and from the 512 sampling points, $135(26 \%)$ had arsenic concentrations above the limit of detection, which was $0.63 \mathrm{mg} \cdot \mathrm{kg}^{-1}$. It was also found that $1063 \mathrm{rd}$ order catchment basins had values above the third quartile, $\left(5.09 \mathrm{mg} \cdot \mathrm{kg}^{-1}\right)$. The results show that high concentrations of this element are strongly related to the presence of Nova Lima rocks that contain minerals rich in arsenic. However, the anthropogenic influence in such high concentrations cannot be ruled out, as the region has a history of over 300 years of gold mining.

Keywords: Geochemical Mapping, Arsenic, Surface water, Stream sediments, Quadrilátero Ferrífero

\section{Resumo}

Um estudo regional da concentração do arsênio em águas superficiais e sedimentos fluviais com uma alta densidade de amostragem de uma amostra para cada $13 \mathrm{~km}^{2}$ foi conduzido pela primeira vez no Quadrilátero Ferrífero (Brasil). A região foi dividida em bacias de $3^{a}$ ordem, sendo amostrados 512 trechos nessas bacias. A concentração de As foi determinada nas águas e nos sedimentos, após digestão parcial, com o auxílio de um ICP-OES. Os valores de arsênio encontrados nas águas superficiais variaram entre 57.70 e $414 \mu g . L^{-1}$. Já para os sedimentos de corrente, as concentrações oscilaram entre 0.63 e $1691 \mathrm{mg} \mathrm{kg}^{-1}$, sendo que dos 512 pontos de amostragem 135 (26\%) apresentaram concentrações de arsênio acima do limite de detecção, que é de 0,63 mg. $\mathrm{kg}^{-1}$. Também foram encontradas 106 bacias de $3^{a}$ ordem com valores acima do $3^{\circ}$ quartil $\left(5.09 \mathrm{mg}^{\mathrm{kg}} \mathrm{kg}^{-1}\right)$. Os resultados mostram que as elevadas concentrações deste elemento estão fortemente relacionadas com a presença de rochas do grupo Nova Lima, que contém minerais ricos em arsênio. Porém, a influência antrópica na existência destas elevadas concentrações não pode ser descartada, já que a região apresenta um histórico de mais de 300 anos de exploração de ouro.

Palavras-chave: mapeamento geoquímico, arsênio, águas superficiais, sedimentos de 


\section{Introduction}

Arsenic is a trace element, whose average concentration in the earth's crust has been set to values between 1.0 (Taylor and McLennan 1995) and 4.8 ppm (Rudnick and Gao 2003). Its occurrence is associated with certain types of minerals, mainly arsenopyrite (FeAsS), loellingite (FeAs2), realgar (As4S4) and arsenian pyrite (FeS2), which can be released to waters, soils and sediments by oxidation processes of these sulfides, and immobilized via adsorption into iron, aluminum and manganese oxides/ hydroxides or into clay minerals (Deschamps et al. 2003). These processes occur naturally but can be intensified by the action of mining activities, with the exposure of large volumes of rocks.

The occurrence of high arsenic concentrations in various environmental compartments, whether natural or amplified by human activities, has become a public health problem, greatly increasing the concern of society and the scientific community regarding human contamination by this element (Fewtrell et al. 2005; Ravenscroft, 2009). According to
Reimann et al. (2009), this was the first chemical element to be recognized for its carcinogenic properties, being used as a poison since the times of the Romans. The inorganic form is recognized as the most harmful to humans, and chronic exposure can cause serious metabolic problems, including hyperkeratosis, skin cancer, lung cancer, nervous system disorders, increased frequency of miscarriages and other serious diseases (Abernathy et al. 1998).

However, the most common form of human exposure is through consumption of contaminated water (Matschullat et al. 2000; Nordstrom, 2002). Not surprisingly, the interest in arsenic exponentially increased after incidents occurred in Bangladesh, West Bengal, India and Mexico caused by consumption of contaminated ground water extracted from aquifers located in arsenic geological formations (Matschullat, 2000, Smith et al. 2002; Neumann et al. 2010).

Despite dozens of published articles, particularly at the end of the last century, the anthropogenic contribution to the high arsenic concentrations in various environmental compartments is not well defined, being a source of much debate. However, determining the natural abundance of arsenic is essential not only to support the analysis and environmental monitoring, but also to support actions to combat pollution (Deschamps et al. 2003). In this sense, with the introduction of new digital mapping technologies, geochemical maps have assumed an increasing relevance in recent years (Gielen 1998). These georeferenced maps allow observing the variation of the abundance of some chemical element in a specific area, thus contributing to the recognition of regions with anomalous values and contributing to the identification of its main sources, whether natural or linked to human activities (Plant et al. 2001).

In this context, the present study aimed to perform the mapping of arsenic concentrations in water and stream sediments of the Quadrilátero Ferrífero using data of 512 sampling points distributed over its $7,000 \mathrm{~km}^{2}$.

\section{Study Area}

\section{The Quadrilátero Ferrífero}

The Quadrilátero Ferrífero is one of the richest regions in economic minerals in the world, covering an area of approximately $7,000 \mathrm{~km}^{2}$, whose exploration history dates back to the last decades of the seventeenth century.

The region includes fully or partly 35 municipalities in the mid region of the state of Minas Gerais, Brazil (Figure 1 ), with a population of over $4,135,000$ inhabitants (IBGE, 2010).

Mining is still among the pro-

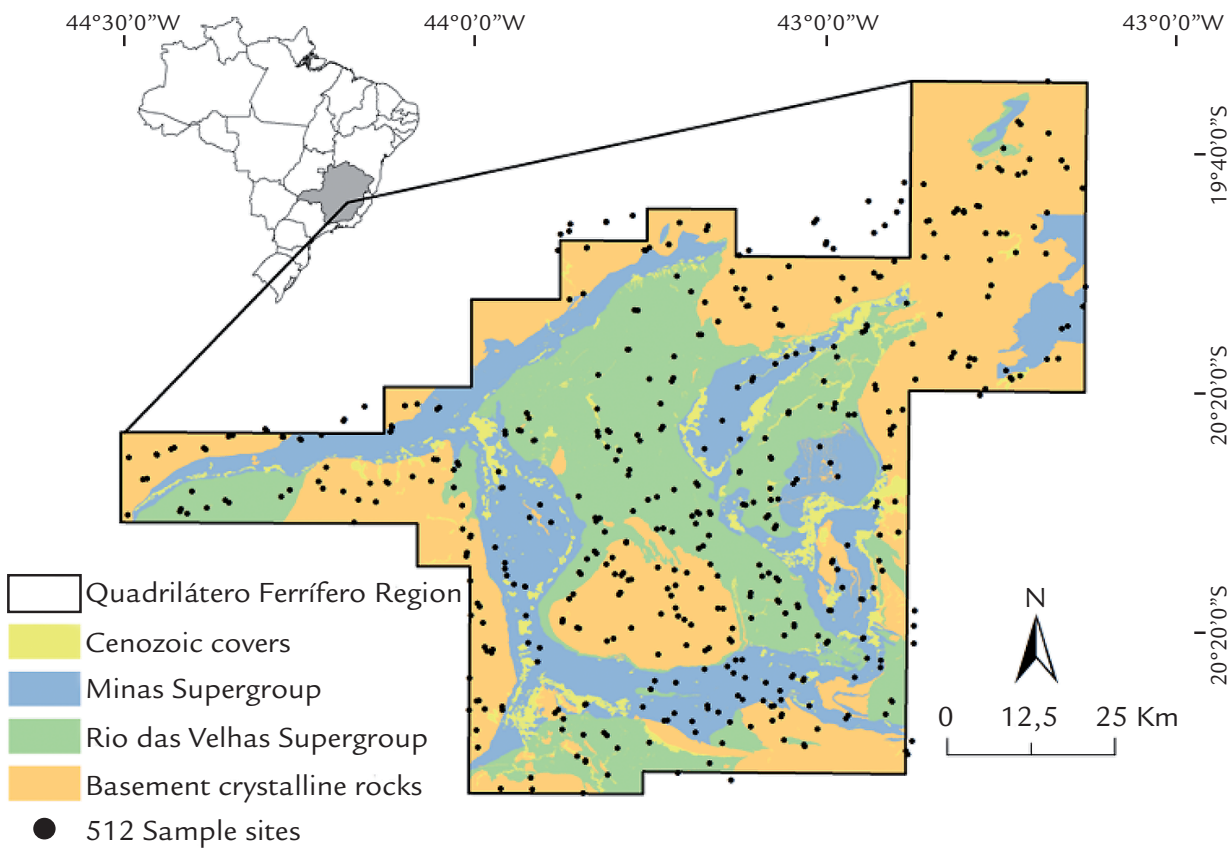

ductive activities that support the region's economy, highlighting the current iron exploitation, which contributes with $26.8 \%$ of the GDP(Gross domestic product) of Minas Gerais (IBGE, 2010).
Figure 1

Geologic map of the QF region, showing the distribution of basement crystalline rocks, Rio das Velhas Supergroup, Minas Supergroup Cenozoic Covers and the location of the sample points. 


\begin{tabular}{|c|c|c|c|c|c|c|c|c|}
\hline \multirow{3}{*}{ References } & \multirow{3}{*}{ Basin } & \multirow{3}{*}{$\begin{array}{c}\text { Num- } \\
\text { ber of } \\
\text { Sampling } \\
\text { Points }\end{array}$} & \multicolumn{6}{|c|}{ As concentration } \\
\hline & & & \multicolumn{3}{|c|}{ Water $\left(\mu g . l^{-1}\right)$} & \multicolumn{3}{|c|}{ Stream Sediments (mg.kg-1) } \\
\hline & & & Min & Mean & Max & Min & Mean & Max \\
\hline \multirow{3}{*}{$\begin{array}{c}\text { Borba et al. } \\
2000\end{array}$} & $\begin{array}{c}\text { Velhas } \\
\text { River } \\
\text { Basin } \\
\text { - Nova } \\
\text { Lima }\end{array}$ & 11 & \multirow{3}{*}{2} & - & 160 & \multirow{3}{*}{20} & - & 2830 \\
\hline & $\begin{array}{c}\text { Carmo } \\
\text { River } \\
\text { Basin } \\
\text { - Ouro } \\
\text { Preto e } \\
\text { Mariana }\end{array}$ & 8 & & - & 30 & & - & 860 \\
\hline & $\begin{array}{l}\text { Con- } \\
\text { ceição } \\
\text { River } \\
\text { Basin - } \\
\text { Santa } \\
\text { Bárbara }\end{array}$ & 7 & & - & 8 & & - & 135 \\
\hline $\begin{array}{l}\text { Matschullat } \\
\text { et al. } 2000\end{array}$ & $\begin{array}{c}\text { Nova } \\
\text { Lima and } \\
\text { Santa } \\
\text { Bárbara }\end{array}$ & $\begin{array}{c}18 \\
\text { (water) } \\
\text { and } 15 \\
\text { (stream } \\
\text { sedi- } \\
\text { ments) }\end{array}$ & 0.4 & 30.5 & 350 & 22 & 350 & 3200 \\
\hline \multirow{3}{*}{$\begin{array}{l}\text { Deschamps } \\
\text { et al. } 2002\end{array}$} & $\begin{array}{l}\text { Nova } \\
\text { Lima }\end{array}$ & 24 & - & - & - & 47 & - & 3300 \\
\hline & $\begin{array}{l}\text { Santa } \\
\text { Bárbara }\end{array}$ & 18 & - & - & - & 22 & - & 160 \\
\hline & Mariana & 9 & - & - & - & 22 & - & 860 \\
\hline \multirow{3}{*}{$\begin{array}{c}\text { Borba et al. } \\
2003\end{array}$} & $\begin{array}{c}\text { Velhas } \\
\text { River Ba- } \\
\text { sin- Nova } \\
\text { Lima }\end{array}$ & 9 & 3 & 67.2 & 349 & 34 & 583.5 & 2830 \\
\hline & $\begin{array}{c}\text { Carmo } \\
\text { River } \\
\text { Basin } \\
\text { - Ouro } \\
\text { Preto and } \\
\text { Mariana }\end{array}$ & $\begin{array}{c}8 \text { (water) } \\
\text { and } 7 \\
\text { (stream } \\
\text { sedi- } \\
\text { ments) }\end{array}$ & 1.7 & 116.7 & 830 & 105 & 819.8 & 4709 \\
\hline & $\begin{array}{l}\text { Con- } \\
\text { ceição } \\
\text { River } \\
\text { Basin- } \\
\text { Santa } \\
\text { Bárbara }\end{array}$ & $\begin{array}{c}13 \text { (wa- } \\
\text { ter) and } \\
6 \text { (stream } \\
\text { sedi- } \\
\text { ments) }\end{array}$ & 1 & 7.7 & 74 & 29.5 & 73.2 & 153 \\
\hline $\begin{array}{l}\text { Pimentel et } \\
\text { al. } 2003\end{array}$ & $\begin{array}{l}\text { Munici- } \\
\text { palities } \\
\text { of Ouro } \\
\text { Preto and } \\
\text { Mariana }\end{array}$ & $\begin{array}{l}22 \text { (wa- } \\
\text { ter) and } 4 \\
\text { (rocks) }\end{array}$ & 0.05 & 0.36 & 2.3 & 0.11 & 60 & 139 \\
\hline \multirow{2}{*}{$\begin{array}{c}\text { Matschullat } \\
\text { et al. } 2007\end{array}$} & $\begin{array}{l}\text { Nova } \\
\text { Lima }\end{array}$ & \multirow{2}{*}{$\begin{array}{c}69 \\
\text { (water) } \\
\text { and } 39 \\
\text { (stream } \\
\text { sedi- } \\
\text { ments) }\end{array}$} & 2.2 & 49 & 350 & 40 & 140 & 3300 \\
\hline & $\begin{array}{l}\text { Santa } \\
\text { Bárbara }\end{array}$ & & 0.4 & 1.8 & 3.1 & 15 & 47 & 170 \\
\hline $\begin{array}{l}\text { Parra et al. } \\
2007\end{array}$ & $\begin{array}{c}\text { Con- } \\
\text { ceição } \\
\text { River } \\
\text { Basin }\end{array}$ & 25 & - & - & - & 4.91 & 51.0 & 89.0 \\
\hline $\begin{array}{l}\text { Varejão et } \\
\text { al. } 2010\end{array}$ & $\begin{array}{c}\text { Carmo } \\
\text { River } \\
\text { Basin } \\
\text { - Ouro } \\
\text { Preto and } \\
\text { Mariana }\end{array}$ & 4 & 36.7 & 54.6 & 68.3 & 68.8 & 1773.9 & 3939 \\
\hline
\end{tabular}

Summary of the main studies on arsenic in waters and sediments sampled in the Quadrilátero Ferrífero. 
Five main lithostratigraphic units are found in the Quadrilátero Ferrífero with ages ranging from the Archean: Metamorphic Complex (Noce, 1995; Alkmim and Marshak, 1998) and Rio das Velhas Supergroup (Alkmim and Marshak , 1998), to the Proterozoic: Minas Supergroup and Itacolomi Group (Dorr II, 1969; Alkmim and Marshak, 1998), and occurrences of mafic and granitic intrusions of several generations (Dorr II, 1969; Marshak and Alkmim, 1998). Its richness in mineral resources and enormous structural and lithological variability directly influence the distribution and geochemical characteristics of its waters, soils and sediments.

In the Quadrilátero Ferrífero,

\section{Methodology}

\section{1 - Sampling points}

The choice of the sampling points was based on methodology proposed by Bolviken et al. (1996), with water and sediment collection carried out in

\section{2 - Sample collection and treatment}

Water samples were collected at the center of each stretch, filtered with the aid of a cellulose acetate membrane (Millipore $0.45 \mu \mathrm{m}$ ) and acidified with three drops of nitric acid (USEPA, 2001).

Then, they were sent for reading in Inductively Coupled Plasma Optical Emission Spectrometry (ICP-OES), label SPECTRO / MODEL Ciros CCD at the Laboratory of Geochemistry of the Federal University of Ouro Preto, where the As concentration was analyzed.

As there is no standard methodology for sediment collection aimed at geochemical characterization, the adopted methodological procedures arsenic has a close relationship with gold deposits present in minerals such as arsenopyrite, löllingite or as an impurity in arsenopyrite (Borba et al. 2000; Figueiredo et al. 2006).

These gold deposits are associated with shear zones that cross rocks from the Nova Lima Group, base of the Rio das Velhas Supergroup, or are located at the base of the Minas Supergroup, near the contact with the Nova Lima Group, in quartz and carbonate veins (Borba et al. 2000; Matschullat et al. 2000; Mello et al. 2006).

Its genesis is related to hydrothermal processes that follow successive deformation phases recorded in the geologic history of the Quadrilátero Ferrífero (Barbosa and Sabaté, 2004)
Although the presence of arsenic in waters and sediments of the Quadrilátero Ferrífero has been long recognized, there are few studies that specifically address this issue.

Table 1 shows a summary of the most important studies. As observed, the works developed so far have focused on only 3 regions of the Quadrilátero Ferrífero: in the municipality of Nova Lima, the Velhas River Basin; in the municipalities of Ouro Preto and Mariana, the Carmo River Basin, and in the municipality of Santa Barbara, the Conceição River Basin.

On average, these studies relied on only 17 water sampling points and 13 points for the collection of sediments, featuring local studies. $3^{\text {rd }}$ order stretches (Strahler, 1952) of catchment basins. In the present work, these stretches were determined based on the hydrographic map of the region on a 1:25,000 scale, provided by the Institute of Water Management of the State of Minas Gerais (IGAM), totaling 512 sampling points (Figure 1). aimed to be as representative as possible, based on the characteristics of stream sediments sampled.

Thus, nine samples were obtained from each stretch. Thus, three subsamples were collected from a region of riffles, 3 subsamples from a region of pools and 3 subsamples from an area of transition between these two morphologies.

For each morphological area, samples were collected at the right bank, left bank and center of the river, and samples collected at the banks were collected at a distance of $0.50 \mathrm{~m}$ from the riverbed.

Also in the field, the subsamples were mixed so as to obtain a representative sample of the stretch. After complete homogenization, quartering was performed to obtain a sample of $500 \mathrm{~g}$, which was packed in plastic bags, according to recommendations of EPA (Environmental Protection Agency) (USEPA, 2001).

In the laboratory, samples were dried under a controlled temperature at $40 \pm 5^{\circ} \mathrm{C}$, crushed, sieved and the sieve fraction smaller than $0.063 \mu \mathrm{m}$ was digested in aqua regia (Calmano and Forstner 1996). Once digested, the final product was analyzed in ICP-OES, where the arsenic content of each sample was determined.

\section{3 - Statistical processing and map presentation}

With the aid of the $\operatorname{ArcMap}^{\circledR} 9.3$ software and based on the geological map of the Quadrilátero Ferrífero on a 1:25,000 scale (Lobato et al. 2005), the percentage of all lithologies and geological formations that make up each of the $3^{\text {rd }}$ order catchment basins sampled was calculated.

\section{Results and Discussion}

Figures 2 and 3 respectively show the geochemical maps with the arsenic distribution in waters (Figure 2) and
With the results, basic statistical parameters were determined and data normality was evaluated by the Komolgorov-Smirnov test.

The methodology defined by Reimann et al. (2005) was used to determine the background values, with the construction of boxplot-type curves and

stream sediments (Figure 3) of the Quadrilátero Ferrífero.

Figure 4 shows the combined cumulative frequency histograms. Based on the geochemical analysis results and using the ArcMap ${ }^{\circledR} 9.3$ software, maps showing the arsenic concentration in waters and stream sediments were constructed using a 1:150,000 scale and the IDW (inverse distance weight) method for interpolation.

graphic representation of histograms, data density and boxplots for the same results. 
Figure 2

Geochemical map showing the variation of As concentrations found in surface waters of the Quadrilátero Ferrífero.

Figure 3

Geochemical map showing the variation of As concentrations found in stream sediments of the Quadrilátero Ferrífero.
44'30"0'W

$44^{\prime} 0^{\prime \prime} 0^{\prime} \mathrm{W}$

$4^{4} 30^{\prime \prime} 0^{\prime} \mathrm{W}$

$43^{\prime} 0{ }^{\prime \prime} \mathrm{O}^{\prime} \mathrm{W}$
I

AS $(\mu g / L)$

Surface waters

$\square$ Quadrilátero Ferrí
$<57,7 \mu \mathrm{g} / \mathrm{L}$
$>3^{\text {rd }}$ quartite (Q3

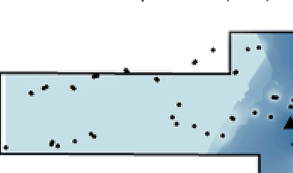

High: 413,77

Low: 57,7

44'30"0'W

44'0"0'W

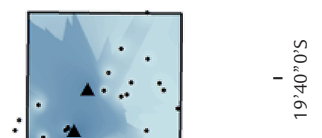

$n$
0
0
0
0
0
0
$\gamma$

$\tilde{n}$
-0
Oे
ì

\section{AS (mg/kg)}

Stream sediments

:

$<$ Quadrilátero Fe
$<5,09 \mathrm{mg} / \mathrm{Kg}$

$>3^{\text {rd }}$ quartite (Q3)

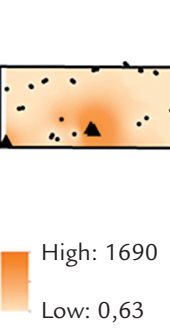

$\cdot \cdots$

ero Region:

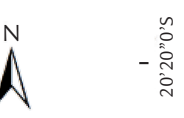

$0 \quad 12,5 \quad 25 \mathrm{Km}$
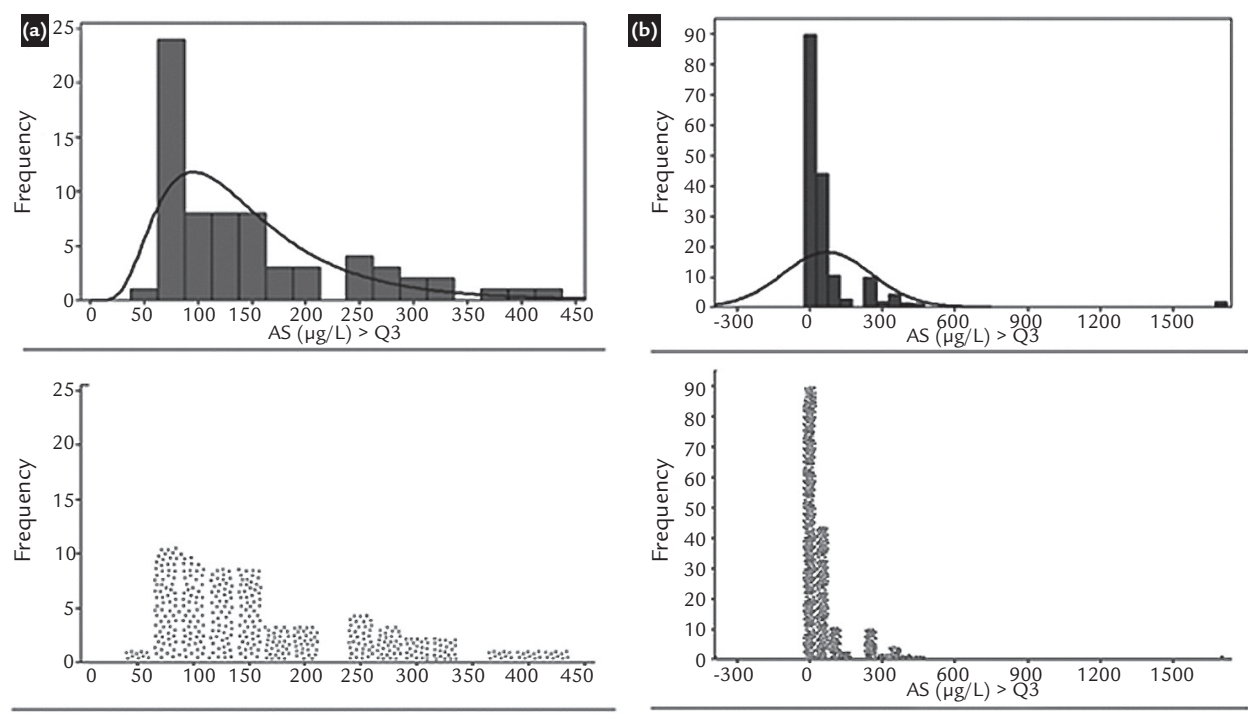

Figure 4

Combined graphic representation showing histogram, data density and boxplot to determine the background of water samples $(A)$ and stream sediments (B) of the Quadrilátero Ferrífero.
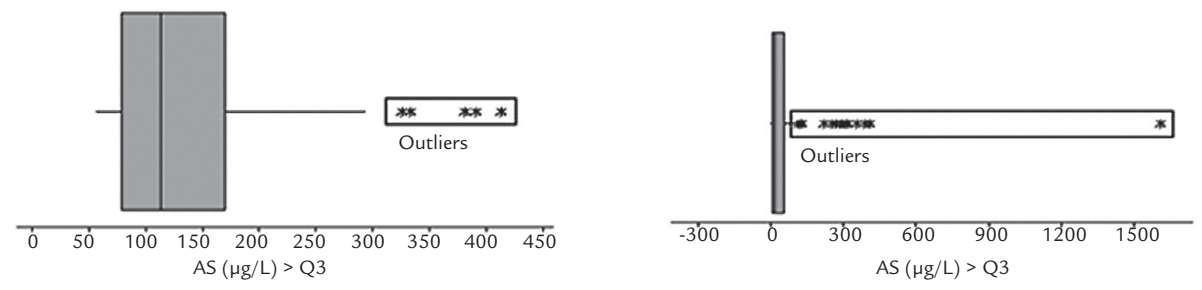
The arsenic values in surface water ranged from $<57.70$ to $414 \mu \mathrm{g}$. $\mathrm{L}^{-1}$. A number of 70 sampling points $(13.7 \%)$, have values of arsenic above the quantification limit of $57.7 \mu \mathrm{g} . \mathrm{L}^{-1}$, which in this case was considered as the background value, because most of the sample points $(86.7 \%)$ showed concentrations up to this level. As surface waters can have arsenic concentrations ranging from $0.5 \mu \mathrm{g} \mathrm{L}^{-1}$ to more than $5000 \mu \mathrm{g} \mathrm{L}^{-1}$, with the most common values below $10 \mu \mathrm{g} \mathrm{L}^{-1}$, and often less than $1 \mu \mathrm{g}$ $\mathrm{L}^{-1}$ (Smedley and Kinniburgh, 2002), the obtained high limit of quantification value did not allow a more detailed statistical analysis of water samples. However, the distribution of points with values above the limit of quantification show important trends, with waters rich in As occurring not only in the Carmo River (Borba et al. 2000; Deschamps et al. 2002; Borba

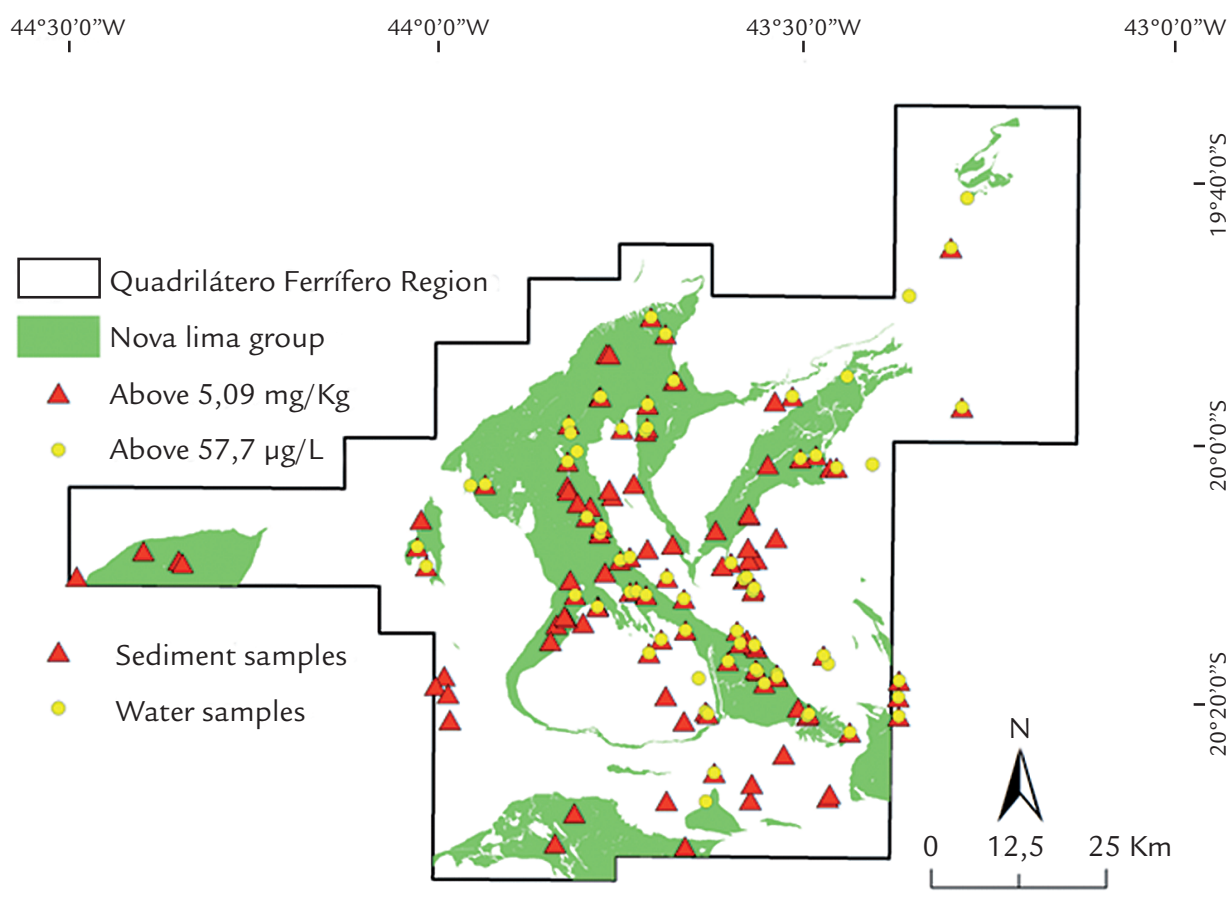

\begin{tabular}{c|c|c|c|c|c|c|c}
$\begin{array}{c}\text { Rocks } \\
\text { from the } \\
\begin{array}{c}\text { Nova } \\
\text { Lima } \\
\text { Group }\end{array}\end{array}$ & Mean & $\begin{array}{c}\text { Standard } \\
\text { deviation }\end{array}$ & Minimum & Q1 (25\%) & $\begin{array}{c}\text { Median } \\
(50 \%)\end{array}$ & Q3 (75\%) & $\begin{array}{c}\text { Maxi- } \\
\text { mum }\end{array}$ \\
\cline { 2 - 8 }$\leq 20$ & 19.63 & 24.52 & 0.63 & 0.63 & 5.37 & 8.71 & 83.70 \\
\hline $\begin{array}{c}20<x \leq \\
30\end{array}$ & 21.87 & 29.86 & 0.63 & 0.63 & 5.37 & 8.71 & 83.70 \\
\hline $\begin{array}{c}30<x \leq \\
40\end{array}$ & 56.2 & 87.2 & 0.63 & 0.63 & 13.68 & 26.82 & 122.6 \\
\hline $\begin{array}{c}40<x \leq \\
50\end{array}$ & 73.8 & 116 & 0.63 & 3.8 & 17.60 & 32.27 & 374.1 \\
\hline $\begin{array}{c}50<x \leq \\
60\end{array}$ & 79.38 & 105.6 & 0.63 & 5.6 & 21.46 & 48.35 & 374.1 \\
\hline $\begin{array}{c}60<x \leq \\
70\end{array}$ & 90.4 & 128 & 3.45 & 7.1 & 30.83 & 62.91 & 407.4 \\
\hline$>70$ & 179 & 267 & 5.87 & 9.32 & 90.71 & 104 & 1691 \\
\hline
\end{tabular}

et al. 2003; Varejão et al. 2011), Velhas River (Borba et al. 2000; Matschullat et al. 2000; Deschamps et al. 2002; Borba et al. 2003, Matschullat et al. 2007) and Conceição River basins (Borba et al. 2000; Matschullat et al. 2000; Deschamps et al. 2002; Borba et al. 2003, Matschullat et al. 2007), but also in the Paraopeba and Piracicaba River basins.

For stream sediments, arsenic concentrations ranged from $<0.63$ to 1691 mg. $\mathrm{kg}^{-1}$, and from the 512 sampling points, $135(26 \%)$ had arsenic concentrations above the limit of quantification, which was $0.63 \mathrm{mg} \cdot \mathrm{kg}^{-1}$. It was also found that $1063^{\text {rd }}$ order catchment basins had values above $5.09 \mathrm{mg} \cdot \mathrm{kg}^{-1}$, considered the background value. These sampling points are mostly composed of tributaries of the main local rivers, and another 35 in rural communities or suburban localities.

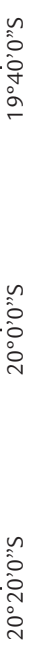
Figure 5 Map showing the distribution of the Nova Lima Group and the sampling points with the highest As concentrations in stream sediments.

Table 2

Relationship between the percentage of occurrence of rocks from the Nova Lima Group in $3^{\text {rd }}$ order catchment basins of the Quadrilátero Ferrífero and as values found in the sediments analyzed.
These locations often have low-income and low-education populations, which exposed to.

The highest values found in stream sediments (between 33 and 1691 mg. $\mathrm{kg}^{-1}$ ) are related to a substratum composed of ricite- chlorite-quartz schist, sericite ist, carbonaceous schist, quartz-micaschist and chlorite schist, rock group, Nova Lima Group (Figure 5).

Among the sixteen $3^{\text {rd }}$ order catchment basins with the highest concentrations (101.7 to $1691 \mathrm{mg} \cdot \mathrm{kg}^{-1}$ ), fourteen have an area greater than $60 \%$ draining on the above mentioned rocks (Table 2), which indicates a strong relationship between the lithological type and the presence of arsenic in the sediment (Figure 5 and Table 2). 
Analyzing the relationship between geology and the arsenic values obtained (Table 2), it appears that the basins with the highest percentages of rocks from the Nova Lima Group had Q3 values far greater than any other rock type. When considering the rock types outcropping in these basins, basins with more than 50\% of their area on sericite-chlorite-quartz schist have $75 \%$ of rivers with arsenic concentrations up to $48.35 \mathrm{mg} . \mathrm{kg}^{-1}$. On the other hand, basins with more than $60 \%$ of their area draining on sericite schist and carbonaceous schist showed Q3 value equal to $62.91 \mathrm{mg} \cdot \mathrm{kg}^{-1}$, and finally, rivers that cross basins with over $70 \%$ of quartz- mica-chlorite schists and chlorite schists have Q3 value of $104 \mathrm{mg} \cdot \mathrm{kg}^{-1}$. This analysis is particularly interesting when these values are compared to data obtained from other lithologies predominating in the IQ such as itabirites and hema-

\section{Conclusions}

A regional study on the arsenic concentration in surface waters and stream sediments, with a robust density of one sample every $13 \mathrm{~km}^{2}$, was carried out for the first time in Quadrilátero Ferrífero (Brazil). This enabled the construction of geochemical maps with the spatial distribution of this element, not available so far.

High arsenic concentrations, potentially harmful to human health, were found in both waters and stream

\section{Acknowledgements}

The authors thankfully and gladly acknowledge the financial support of

\section{References}

tites, dolomites and limestones, gneisses and granites, ferruginous quartzites, and various types of phyllites, which showed significantly lower arsenic concentrations, with Q3 values near zero.

Most of the high As concentrations found in Quadrilátero Ferrífero, either in waters or in stream sediments, are derived from rocks rich in this element. Confirming this hypothesis, it was found that several points considered anomalous were within Conservation Units (CUs) or Permanent Preservation Areas (PPAs), in which, theoretically, human interference is minimized. Examples are OP 23 (306.2 mg. kg $\left.{ }^{-1}\right)$, OP 24 (130 mg. $\left.\mathrm{kg}^{-1}\right)$, OP 30 (374.1 mg. $\left.\mathrm{kg}^{-1}\right)$ and OP 31 (101.7 mg.kg $\left.{ }^{-1}\right)$, located in the PPA of Cachoeira das Andorinhas, and OP 35, OP 36 and OP 38 that are within the Uaimii forest, which have As values in the sediments above $49.7 \mathrm{mg} \cdot \mathrm{kg}^{-1}$.

sediments. In the case of waters, values greater than $57.70 \mu \mathrm{g}$. $\mathrm{L}^{-1}$ were found in all three major basins that cross the Quadrilátero Ferrífero: Velhas River, Doce River and Paraopeba River, and this is the first time that such concentrations have been reported in the Paraopeba River Basin.

In relationship to stream sediments, one fifth of the sampling points showed values above $5.09 \mathrm{mg} \cdot \mathrm{kg}^{-1}$. Points whose concentrations were
According to the map shown in Figure 5, it appears that most of the anomalies are located within the mid-northern region of the IQ, which despite having geological substratum rich in arsenic, is also characterized as having a high concentration of mining companies exploiting gold in Nova Lima, Sabará and Caeté, and iron in Nova Lima, Ouro Preto, Itabirito, Sabará, Santa Barbara and Caeté. Furthermore, much of the Quadrilátero Ferrífero region was intensively exploited for the removal of gold between the seventeenth and nineteenth centuries, showing evidence of extraction processes in this period, including mines and waste dumps (Fonseca et al. 2001). The presence of mining activity for the removal of gold, in the current or past centuries, can accelerate the availability of elements for the environment, including As (Ripley et al. 1996; Matschullat et al. 2007, Espinosa et al. 2009).

above $101 \mathrm{mg} \cdot \mathrm{kg}^{-1}$ occurred in basins with $60 \%$ or more of their area formed by rocks that compose the Nova Lima Group, Rio das Velhas Supergroup.

Although data have shown that arsenic occurs naturally in the Quadrilátero Ferrífero, the possibility that human action has contributed to increase these concentrations cannot be ruled out, particularly in areas where there are still caves and waste dumps from gold mining of ancient centuries.

the institutions CNPq, FAPEMIG and mainly CAPES for the scholarship Proc. no 10228/13-6.

ABERNATHY, C. O., CALDERON, R. L., CHAPPELL, W. R. Arsenic exposure and health effects. San Diego, California: Elsevier, 1998.

ALKMIM, F. F., MARSHAK, S. Transamazonian Orogeny in the Southern São Francisco Craton Region, Minas Gerais, Brazil: evidence for Paleoproterozoic collision and collapse in the Quadrilátero Ferrífero. Precambrian Research, v. 90, p. 29-58, 1998.

BARBOSA, J. S. F., SABATÉ, P. Archean Paleoproterozoic crust of the São Francisco Craton, Bahia, Brazil: geodynamic features. Precambrian Research, v. 133, p. 1-27, 2004.

BERNASCONI, A. Archaean gold mineralization in central Brazil: a review. Mineralium Deposita, v. 20, p. 277-283, 1985.

BÖLVIKEN, B., BOGEN, J., DEMETRIADES, A., DE VOS, W., EBBING, J., HINDEL, R., LANGEDAL, M., LOCUTURA, J., O'CONNOR, P., OTTESEN, R. T., PULKKINEN, E., SALMINEN, R., SCHERMAN, O., SWENNEN, R., VAN DER SLUYS, J., VOLDEN, T. Regional geochemical mapping of Western Europe towards the year 2000. Journal of Geochemical Exploration, v. 56, p. 141- 
$166,1996$.

BORBA, R. P., FIGUEIREDO, B. R., RAWLINS, B., MATSCHULLAT, J. Arsenic in Water and Sediment in the Quadrilátero Ferrífero, State of Minas Gerais, Brazil. Applied Geochemistry, v. 15, n. 2, p. 181-190, 2000.

BORBA, R. P., FIGUEIREDO, B. R., MATSCHULLAT, J. Geochemical distribution of arsenic in waters, sediments and weathered gold mineralized rocks from Quadrilátero Ferrífero, Brazil. Environmental Geology, v. 44, n. 1, p. 39-52, 2003.

BORBA, R. P., FIGUEIREDO, B. R. A influência das condições geoquímicas na oxidação da arsenopirita e na mobilidade do arsênio em ambientes superficiais tropicais. Revista Brasileira de Geociências, v. 34, n. 4, p. 489-500, 2004.

CALMANO, W., FÖRSTNER, U., SALOMONS, W., ALLAN, R. Sediments and toxic substances: environmental effects and ecotoxicity. New York: Springer, 1996.

COSTA, A. T. Registro histórico de contaminação por metais pesados, associadas à exploração aurífera no alto e médio curso da bacia do Ribeirão do Carmo, QF: um estudo de sedimentos de planícies de inundação e terraços aluviais. Ouro Preto: Departamento de Geologia, Universidade Federal de Ouro Preto, 2007. 257 p. (Tese de Doutorado).

DESCHAMPS, E., CARNEIRO, M. E. D. P., CIMINELli, V. S. T., PETER, W., RAMOS, A. Arsenic sorption onto soils enriched in Mn and Fe minerals. Clays and Clay Minerals, v. 51, p. 198-205, 2003.

DORR, J. N. Physiographic, stratigraphic, and structural development of the Quadrilátero Ferrífero, Minas Gerais. USGS Professional Paper: 641-A, 1969.

FEWTRELL, L., FUGE, R., KAY, D. An estimation of the global burden of disease due to skin lesions caused by arsenic in drinking water. Journal of Water and Health, v. 3, n. 2, p. 101-107, 2005.

FIGUEIREDO, B. R., BORBA, R. P., ANGÉLICA, R. S. Arsênio no Brasil e exposição humana. In: SILVA, C. R. da et al. Geologia médica no Brasil - efeitos dos materiais e fatores geológicos na saúde humana e meio ambiente. Rio de Janeiro: CPRM, 2006.

FONSECA M., SOBREIRA F., RAINHO M. E., OLIVEIRA M. Unbridled development of urban space and its implications on the preservation of landmarks - the Morro da Queimada archeological site, Ouro Preto, Brazil. Cities, v. 18, n. 6, p. 381-389, 2001.

GIELEN, E. Los SIG en el estudio de los humedales. Boletín SEHUMED. Valência, n. 5, marzo 1998.

INSTITUTO BRASILEIRO DE GEOGRAFIA E ESTATÍSTICA. IBGE: Censo Nacional de 2010. Available: <http://www.censo2010.ibge.gov.br/>. Acessed: 15 may 2013.

LOBATO, L., BALTAZAR, O. F., REIS, L. B. Projeto geologia do quadrilátero ferrífero - integração e correção cartográfica em SIG com nota explicativa. Belo Horizonte: CODEMIG, 2005. 1 CD-ROM.

MACHADO, N., NOCE, C. M., OLIVEIRA, O. A. B., LADEIRA, E. A. Evolução geológica do Quadrilátero Ferrífero no Arqueano e Proterozóico Inferior, com base em geocronologia U-Pb. In: SIMPÓSIO DE GEOLOGIA DE MINAS GERAIS, 5, SIMPÓSIO DE GEOLOGIA DE BRASILIA, 1. Anais... Belo Horizonte: SBG/ Núcleo MG, 1989. p. 1-5.

MATSCHULLAT, J., DESCHAMPS E. Arsênio antropogênico e natural: um estudo em regiões do Quadrilátero Ferrífero. Belo Horizonte: Fundação Estadual do Meio Ambiente, 2007.

MATSCHULLAT, J., BORBA, R. P., DESCHAMPS, E., FIGUEIREDO, B. F., GABRIO, T., SCHWENK, M. Human and environmental contamination in the Quadrilátero Ferrífero, Brazil. Applied Geochemistry, v. 15, p. 181-190, 2000.

MELLO, J. W. V., ROY, W. R., TALBOTT, J. L., STUCKI, J. W. Mineralogy and arsenic mobility in arsenic rich Brazilian soils and sediments. Journal of Soils and Sediments, v. 6, p. 9-19, 2006.

NEUMANN, R. B., ASHFAQUE, K. N., BADRUZZAMAN, A. B. M., ALI, M. A., SHOEMAKER, J. K., HARVEY, C. F. Anthropogenic influences on groundwater arsenic concentrations in Bangladesh. Nature Geoscience Journal, v. 3, p. 46-53, 2010.

NOCE, C. M. Geocronologia dos eventos magmáticos, sedimentares e metamórficos da região do Quadrilátero Ferrífero, Minas Gerais. São Paulo: Instituto de Goeci- 
ências, Universidade de São Paulo, 1995. 127 p. (Tese de Doutorado).

NORDSTROM, D. K. Worldwide occurrences of arsenic in groundwater. Science, v. 296, p. 2143-2145, 2002.

PARRA, R.R., ROESER, H. M. P, LEITE, M. G. P, NALINI JR., H. A., GUIMARÃES, A. T. A., PEREIRA, J. C., FRIESE, K. Influência antrópica na geoquímica de água e sedimentos do rio Conceição, Quadrilátero Ferrífero, Minas Gerais Brasil. Geochimica Brasiliensis, v. 21, n. 1, p. 36 - 49, 2007.

PIMENTEL, H.S., DE LENA, J.C., NALINI JR. H. A. Studies of water quality in the Ouro Preto region, Minas Gerais, Brazil: the release of arsenic to the hydrological system. Environmental Geology, v. 43, p. 725-730, 2003.

PLANT, J., SMITH, D., SMITH, B., WILLIAMS, L. Environmental geochemistry at the global scale. Applied Geochemistry, v. 16, p. 1291-1308, 2001.

RAVENSCROFT, P., BRAMMER, H. Arsenic in groundwater: A threat to sustainable agriculture in South and South-east Asia. Environment International, v. 35, p. 647-654, 2009.

REIMANN, C., GARRET, R. G. Geochemical background - concept and reality. Science of the Total Environment, v. 350, p. 12-27, 2005.

REIMANN, C., MATSCHULLAT, J., BIRKE, M., SALMINEN, R. Arsenic distribution in the environment: The effects of scale. Applied Geochemistry, v. 24, p. 1147-1167, 2009.

RIPLEY, E. A. REDMANN, R. E, CROWDER, A. A. Environmental effects of mining. Florida: St. Lucie Press, 1996.

RODRÍGUES. R., RAMOS, J. A., ARMIENTA, A. Groundwater arsenic variations: the role of local geology and rainfall. Applied Geochemistry, v. 19, p. 245-250, 2004.

RUDNICK, R. L., GAO, S. Composition of the continental crust. In: HEINRICH, H. D., TUREKIAN, K. K. (Org.). Treatise on Geochemistry. Elsevier: v. 3, p. 1-64, 2003.

SMITH, A. H., LOPIPERO, P. A., BATES, M.N., STEINMAUS, C. M. Arsenic epidemiology and drinking water standards. Science, v. 296, p. 2145-2146, 2002.

STRAHLER, A. N. Dynamic basis of Geomorphology, Geological Society. America Bulletin, v. 63, p 923-938, 1952.

TAYLOR S.R \&, MCLENNAN S.M. The geochemical evolution of the continental crust. Geophysics, v. 33, p. 241-265, 1995.

USEPA - UNITED STATES ENVIRONMENTAL PROTECTION AGENCY USEPA. Sediment Sampling Guide and Methodologies. Division of Surface Water. Columbus, 2001. $36 \mathrm{p}$.

VAREJÃO, E. V., BELLATO, C. R., FONTES, M. P. F., MELLO, J. W. V. Arsenic and trace metals in river water and sediments from southeast portion of Quadrilátero Ferrífero, Brazil. Environmental Monitoring Assessment, v. 172, p. 631-642, 2010.

Received: 02 May 2014 - Accepted: 22 October 2014 